
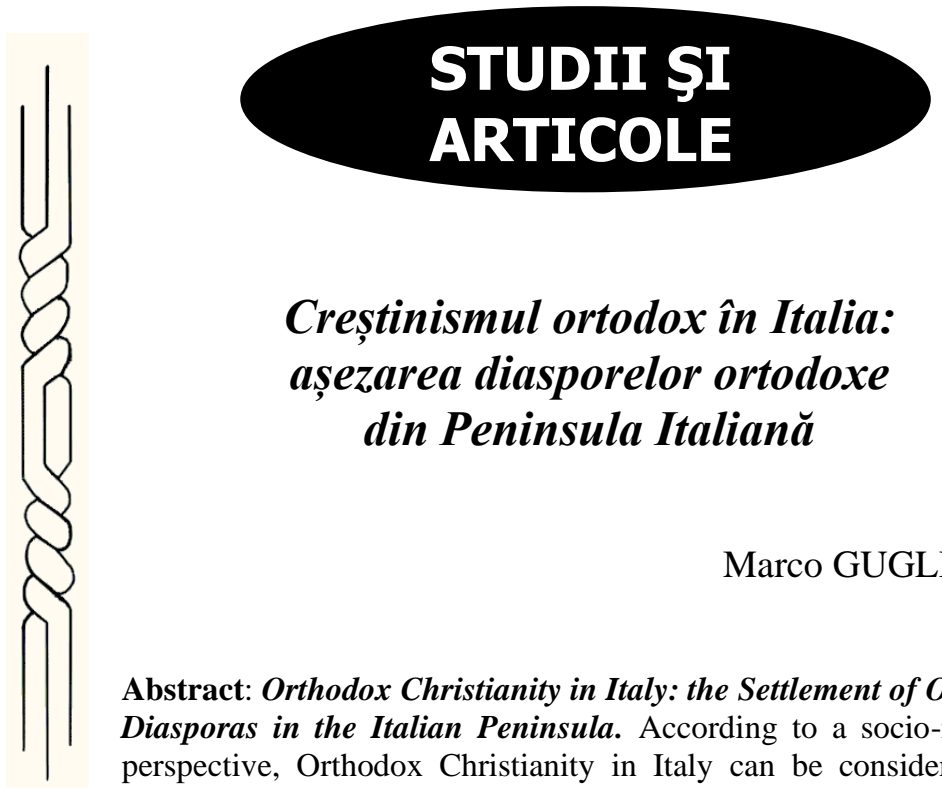

\title{
Creștinismul ortodox în Italia: așezarea diasporelor ortodoxe din Peninsula Italiană
}

\section{Marco GUGLIELMI*}

Abstract: Orthodox Christianity in Italy: the Settlement of Orthodox Diasporas in the Italian Peninsula. According to a socio-religious perspective, Orthodox Christianity in Italy can be considered as a 'Western European Orthodox laboratory'. In this scenario, in fact, some patterns relating to the establishment of Eastern Orthodoxy in Western Europe may be identified. Taking into consideration that in Italy there is the largest number of Orthodox faithful in Western Europe and the largest Romanian diaspora in the world, I focus on the settlement of Orthodox diasporas within the Italian peninsula. The first objective is to offer an overview about the whole Orthodox community in Italy, while the second is to explore the constellation of Orthodox jurisdictions (canonical and noncanonical) in the Italian peninsula. The third aim is to define the paths of engagement with the host context of diasporas of the Romanian Orthodox Church, the Ecumenical Patriarchate, and the Russian Orthodox Church. In short, the article would like to shed fresh light on the establishment and recent sociological developments of Eastern Orthodoxy in Italy.

Keywords: Catholic-Orthodox relations, Italy, Orthodox diaspora, Romanian Orthodox Church, Western Europe.

* Cercetător la Centrul de Studii Religioase al Fundației Bruno Kessler din Trento. Doctorat internațional axat pe sociologia religiei la Universitatea din Padova, împreună cu Universitatea Western Sydney, Universitatea din Zagreb și Universitatea Pantheion. 


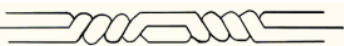

\section{Introducere}

Creștinismul ortodox din Italia are rădăcini istorice străvechi și profunde. $\mathrm{Cu}$ toate acestea, în ultimele două decenii, fațetele sale socio-culturale au fost modificate datorită fenomenului nivelurilor ridicate de migrație din țările est-europene către Italia (Giordan 2015). Această discontinuitate socială a Ortodoxiei pe teritoriul italian devine relevantă din punct de vedere cantitativ și în scenariul internațional. De fapt, cercetările recente au arătat că în Italia există cel mai mare număr de credincioși ortodocşi din Europa Occidentală și cea mai mare diasporă ortodoxă română din lume (Giordan, Guglielmi 2018; Guglielmi 2020). Mai mult decât atât, studiul scenariului italian pare să dezvăluie tendințele studiilor recente privind Ortodoxia răsăriteană în Europa Occidentală, care sugerează că scenariul diasporei ortodoxe implicate exclusiv în asistența comunităților de imigranți a fost depăşit (Giordan, Guglielmi 2018; Ihlamur-Öner 2009; Hämmerli 2011; Hämmerli, Mayer 2014; Rimestad 2020; Roudometof 2015; Giordan, Zrinšcak 2020). Potrivit acestor cercetări, în ultimele două decenii, diasporele ortodoxe din această regiune europeană sunt marcate de transformări mai ales în ceea ce privește practicile și identitățile.

În acest articol mă concentrez asupra creștinismului ortodox din Italia, văzut ca un ,laborator ortodox vest-european”, așa fiind identificate unele modele legate de întemeierea Ortodoxiei în Europa Occidentală. „Potențialul” cazului italian are patru caracteristici principale: prezența celei mai mari diaspore ortodoxe din Europa Occidentală și cea mai mare diasporă ortodoxă română din lume; monopolul virtual al Bisericii Catolice în contextul sociocultural, precum și diversitatea religioasă ,,particulară” mai centrată pe creștinii din Peninsula Italiană (Pace 2011, 2013); așezarea mai multor jurisdicții și episcopi ortodocşi din teritoriu, precum și încălcarea Canonului 28 al Sinodului IV Ecumenic, care acordă Patriarhiei Ecumenice a Constantinopolului o întâietate de onoare 
după episcopul Romei și peste eparhiile „barbare”1. Aici se portretizează un peisaj ortodox fragmentat și eterogen, în care numărul jurisdicțiilor canonice este egal cu cel al jurisdicțiilor necanonice.

Primul obiectiv al articolului este de a oferi o imagine de ansamblu a întregii comunităţi ortodoxe din Italia. Noile date cantitative disponibile permit o analiză a credincioșilor ortodocși la nivel național și indică distribuţia comunităţilor naționale în cadrul principalelor biserici din diaspora a acestei tradiţii religioase. Ulterior, mă concentrez asupra instituțiilor acestui scenariu religios, studiind constelația de jurisdicții canonice interne și externe în raport cu Comuniunea Ortodoxă Răsăriteană. Al treilea scop al articolului este de a oferi o imagine de ansamblu asupra așezării celor trei jurisdicții ortodoxe principale din Italia. În special, mă voi concentra asupra Bisericii Ortodoxe Române (Episcopia Ortodoxă Română a Italiei - Episcopia Ortodoxă Română a Italiei), Patriarhia Ecumenică a Constantinopolului (Arhiepiscopia

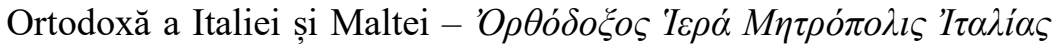

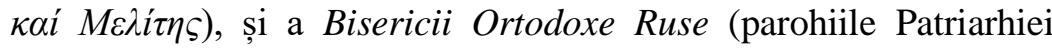
Moscovei din Italia - Приходов Московского Патриархата в Италии). În continuare, voi arăta că acestea au dezvoltat căi diferite de implicare în societate, cu religia dominantă și cu starea contextului italian. Conform rezultatelor cercetării, aș dori să aduc o lumină proaspătă asupra așezărilor și a evoluţiilor sociologice recente ale Ortodoxiei răsăritene din Italia, care apar ca o panoramă creștin-ortodoxă de frunte în Occident.

Datele provin dintr-un proiect de cercetare demarat în noiembrie 2015 (până în prezent) privind așezarea creștinismului ortodox în Peninsula Italiană. Unele date au fost colectate în domeniu prin abordări calitative (interviuri semi-structurale de profunzime și observare participativă), în timp ce altele provin din prelucrarea datelor cantitative furnizate chiar de Bisericile Ortodoxe. În ultimii 6 ani de cercetare, am strâns aproximativ 35 de

\footnotetext{
1 Problema întâietății asupra teritoriilor tradițional eterodoxe este o sursă de conflict întemeiată din motive istorice, teologice şi eclesiologice. Pentru o problematizare a acestei probleme, a se vedea Hämmerli (2010).
} 
interviuri aprofundate în Italia și am putut fi, de asemenea, bursier invitat la Patriarhia Română din București timp de 3 luni.

\section{Credincioșii ortodocși din Italia}

Fundația ISMU oferă o sursă credibilă de date privind relația dintre religie și migrație în Italia. Cea mai recentă estimare furnizată indică un număr mai mare de credincioși ortodocși, care depășesc numărul musulmanilor cu câteva mii.

Tabelul 1. Aderarea religioasă a imigranților în Italia (2020)

\begin{tabular}{|l|l|l|}
\hline Catolici & Ortodocși & Musulmani \\
\hline $1,080,000$ & $1,578,000$ & $1,574,000$ \\
\hline
\end{tabular}

Sursa: ISMU (2020)

Conform Tabelului 1, creștinismul ortodox deține locul celei de-a doua religii imigrante ca mărime în Italia, după romanocatolici. În plus, conform estimărilor anterioare ale aceleiași instituții (ISMU 2016), Ortodoxia răsăriteană pare să fie mai răspândită în regiunile din nordul Italiei (Lombardia 265.200, Veneto 175.500, Piemont 162.900, Emilia-Romagna 156.700) și în unele regiuni centrale (Toscana 116.400, Marche 40.700), cu cei mai mulți în regiunea Lazio (259.900). Creștinismul ortodox pare să fie mai puţin prezent în regiunile din sudul Italiei (cu o prezență maximă în regiunea Campania, cu 84.800 de credincioși); din punct de vedere geografic, aceste date reflectă situația pieței muncii italiene și cea a distribuției populației imigrante în țară. Pe scurt, mai mult de jumătate dintre credincioșii ortodocși par să trăiască în regiunile nordice ale Italiei $(53,8 \%)$, iar o treime în cele două regiuni Lombardia și Lazio (32,7\%).

Această mare prezență ortodoxă în Italia poate fi recunoscută în interior și justificată datorită prezenței masive a imigranților români în Peninsula Italiană, care a crescut incredibil în ultimele două decenii. După cum se arată în tabelul 2, care conține estimările numărului de români din Italia conform Institutului Naţional Italian 
de Statistică (ISTAT), fluxul ${ }^{2}$ românilor s-a accelerat inițial după 2002, odată cu liberalizarea vizelor turistice în România. În schimb, în 2007 poate fi identificată a doua accelerare relevantă și este motivată de intrarea României în Uniunea Europeană, aceasta recunoscând dreptul la liberă circulație pe teritoriul european din partea cetățenilor români.

Tabelul 2. Numărul imigranților români în Italia.

\begin{tabular}{|c|c|}
\hline 2001 & 74,885 \\
\hline 2002 & 95,039 \\
\hline 2003 & 177,812 \\
\hline 2004 & 248,849 \\
\hline 2005 & 297,570 \\
\hline 2006 & 342,200 \\
\hline 2007 & 625,278 \\
\hline 2008 & 796,477 \\
\hline 2009 & 887,763 \\
\hline 2010 & 968,576 \\
\hline 2011 & 823,100 \\
\hline 2012 & 933,354 \\
\hline 2013 & $1,081,400$ \\
\hline 2014 & $1,131,839$ \\
\hline 2015 & $1,151,395$ \\
\hline 2016 & $1,168,552$ \\
\hline 2017 & $1,190,091$ \\
\hline 2018 & $1,143,859$ \\
\hline 2019 & $1,145,718$ \\
\hline
\end{tabular}

2 Datele ISTAT-ului sunt disponibile aici: https://www.istat.it. Accesat la 20 august 2021. 
Excluzând declinul din perioada de doi ani 2011-2012, creșterea progresivă a comunității românești din Italia este destul de impresionantă. Nu există răspunsuri istorice și sociologice exhaustive care să clarifice motivațiile ce i-au determinat pe români să emigreze en masse în Italia, constituind aici cea mai mare diasporă a lor la nivel mondial. Pe de altă parte, se pare că un motiv principal poate fi identificat în dimensiunea socioculturală: într-un anumit sens, România, ca și Italia, are un caracter latin stabilit în limba și identitatea sa etnică (Pop 1999). Această ,proximitate socio-culturală” pare să fi făcut din Italia un teritoriu privilegiat în ceea ce privește migrația românească, creând procese transnaționale puternice între cele două țări (Cingolani 2009). Nu este o coincidență faptul că Spania, o altă zonă latină, este țara cu a treia cea mai mare diasporă românească din lume. ${ }^{3}$

Tabelul 3. Naționalitățile imigranților din cele trei tradiții creștine

\begin{tabular}{c|c|c|c|c|c|c|c}
\hline Cetățenie & Ortodox & Cetățenie & Catolici & Cetățenie & Protestanţi & Cetățenie & Creştini \\
\hline România & 999,400 & Filipine & 135,000 & România & 68,000 & România & $1,151,000$ \\
\hline Ucraina & 193,000 & Polonia & 94,000 & Nigeria & 20,000 & Ucraina & 226,000 \\
\hline Moldova & 133,000 & Peru & 84,000 & Ghana & 19,000 & Filipine & 152,000 \\
\hline Bulgaria & 42,000 & România & 84,000 & Filipine & 17,000 & Moldova & 135,000 \\
\hline Albania & 41,000 & Ecuador & 80,000 & Germania & 16,000 & Albania & 115,000 \\
\hline $\begin{array}{c}\text { Republica } \\
\text { Macedonia }\end{array}$ & 40,000 & Albania & 74,000 & $\begin{array}{c}\text { Marea } \\
\text { Britanie }\end{array}$ & 15,000 & Peru & 97,000 \\
\hline Alte țări & 93,000 & Alte țări & 357,000 & Alte țări & 100,000 & Alte țări & 828,000 \\
\hline Total & $\mathbf{1 , 5 4 1 , 0 0 0}$ & Total & $\mathbf{9 0 8 , 0 0 0}$ & Total & $\mathbf{2 5 5 , 0 0 0}$ & Total & $\mathbf{2 , 7 0 4 , 0 0 0}$ \\
\hline
\end{tabular}

din Italia (2015)

Sursa: Centrul de studiu „IDOS”.

3 Potrivit datelor furnizate de Ambasada României la Berlin, în Germania sunt 722.404 de cetățeni români în 2019; https://berlin.mae.ro/node/286; accesat la 27 aprilie 2021. Referitor la Spania, în 2019 se preconizează că numărul de cetățeni români se va ridica la 671.985 persoane; https://epa.com.es/ padron/rumanos-en-espana; accesat la 27 aprilie 2021. 
Datele tabelulului 3, din dosarul statistic al imigrației întocmit de Centrul de Studiu „IDOS”, arată naționalitățile prezente în grupul credincioșilor ortodocși din Italia, precum și cele din celelalte două tradiții creștine, adică romano-catolicismul și protestantismul. Deși, aceste estimări nu sunt foarte recente, ele oferă o imagine mai aprofundată a establishment-ului ortodox pe teritoriul italian, precum și a prezenței românești.

Comunitatea ortodoxă română este cel mai mare grup, urmat de cel al imigranților ucraineni și moldoveni. Credincioșii acestor trei comunități naționale reprezintă împreună „bazinul” jurisdicțiilor ortodoxe din Italia. Credincioșii moldoveni și ucraineni constituie majoritatea adepților Bisericii Ortodoxe Ruse din Italia, respectând astfel jurisdicția din care fac parte cele două biserici respective din patria mamă, adică Biserica Ortodoxă Moldovenească și Biserica Ortodoxă Ucraineană. În definiția acestei grupări, un rol cheie îl joacă aspectele etnice și vernaculare comune printre acești credincioși. Mai concret, mă refer la cele legate de cultura lumii slave și utilizarea limbii slave. Pe de altă parte, unii dintre credincioșii ucraineni sunt membri ai parohiilor Patriarhiei Ecumenice, având în vedere prezența în patria lor a Bisericii Ortodoxe nou-înființate a Ucrainei (în decembrie 2018), care se află sub jurisdicția Constantinopolului. În acest sens, și credincioșii moldoveni din Italia sunt influențați de diviziunile din țările de baștină, unde cele două jurisdicții ortodoxe se confruntă cu divizii etnice și lingvistice. Există o Biserică Ortodoxă aflată sub jurisdicția Patriarhiei Moscovei și o Biserică aflată sub jurisdicția Patriarhiei Române, Mitropolia Basarabiei (Grigore 2016). Potrivit acestei situații, moldovenii din Italia sunt în mare măsură prezenți în parohiile rusești și, întro măsură mai mică, se găsesc și în parohiile românești și în cele ale Patriarhiei Ecumenice.

În cele din urmă, datele privitoare la celelalte două tradiții creștine sugerează alte două perspective relevante. Prima reprezintă impactul cantitativ larg al populației românești, care are și a treia cea mai mare comunitate romano-catolică și prima comunitate protestantă a populației imigrante din Italia. Această 
din urmă comunitate de imigranți depășește chiar totalul celor două comunități protestante africane principale din Italia, adică cele ale imigranților nigerieni și ghanezi, care se ridică rapid în peninsula noastră datorită fenomenului inedit al Bisericilor Penticostale Africane (Butticci 2016). Cea de-a doua perspectivă se referă la tendințele întregii dimensiuni creștine a imigranților din Italia, deoarece românii arată influențe considerabile în toate tradițiile creștine. $\mathrm{Nu}$ trebuie subestimată prezența credincioșilor din alte țări cu majoritate ortodoxă, cum ar fi Ucraina, Moldova și Bulgaria sau a celor cu o mare comunitate ortodoxă, aşa cum se întâmplă în Albania.

\section{Jurisdicțiile ortodoxe din Italia}

În această secțiune, mă concentrez asupra jurisdicțiilor ortodoxe din Italia. Tabelul 4 compară numărul jurisdicțiilor ortodoxe și al parohiilor și mănăstirilor acestora din ultimii 10 ani, în special în anii 2011, 2016 și 2021. În 2011 existau 12 jurisdicții ortodoxe şi 326 de parohii prezente pe teritoriul Italiei, în timp ce la începutul anului 2016 existau 14 jurisdicții, cu un total de 443 de parohii distribuite în întreaga țară. În 2021 există din nou 14 jurisdicții ortodoxe, dar cu un total de 516 parohii şi mănăstiri, înregistrând astfel o creștere de $16 \%$ în cinci ani și de 58\% în zece ani. În ceea ce privește jurisdicțiile individuale, datele arată că cea mai semnificativă creștere din ultimii cinci ani a vizat Patriarhia României (29\%) şi Patriarhia Moscovei (14\%). În ceea ce privește celelalte jurisdicții, nu există variații semnificative, sugerând $o$ anumită stabilizare numerică a jurisdicțiilor ortodoxe mai mici din Peninsula Italiană $\breve{4}^{4}$

4 Arhiepiscopia Bisericilor Ortodoxe Ruse din Europa de Vest a fost primită de Biserica Ortodoxă Rusă în 2018, după decizia Patriarhiei Ecumenice, care era jurisdicția Arhiepiscopiei din 1931, de a o dizolva în acelaşi an. Datorită acestei situații controversate, parohiile Arhiepiscopiei din Italia apar numeric scăzute, deoarece unele dintre ele s-au alăturat direct Patriarhiei Ecumenice și Bisericii Ortodoxe Ruse. 
Tabelul 4. Bisericile Ortodoxe din Italia (2011, 2016, 2021)

\begin{tabular}{|c|c|c|c|}
\hline Jurisdicție & $\begin{array}{c}\text { Parohii și } \\
\text { mănăstiri } \\
\text { în ianuarie } \\
\mathbf{2 0 1 1}\end{array}$ & $\begin{array}{c}\text { Parohii și } \\
\text { mănăstiri } \\
\text { în ianuarie } \\
\mathbf{2 0 1 6}\end{array}$ & $\begin{array}{l}\text { Parohii și } \\
\text { mănăstiri } \\
\text { din } \\
\text { Ianuarie } \\
\mathbf{2 0 2 1}\end{array}$ \\
\hline $\begin{array}{l}\text { Biserica Ortodoxă } \\
\text { Română (Patriarhia } \\
\text { României), Eparhia } \\
\text { Italiei }\end{array}$ & 166 & 228 & 294 \\
\hline $\begin{array}{c}\text { Sfânta Arhiepiscopie } \\
\text { Ortodoxă a Italiei și } \\
\text { Maltei (Patriarhia } \\
\text { Ecumenică a } \\
\text { Constantinopolului) }\end{array}$ & 84 & 87 & 87 \\
\hline $\begin{array}{c}\text { Biserica Ortodoxă Rusă } \\
\text { (Patriarhia Moscovei), } \\
\text { Administrația } \\
\text { Bisericilor din Italia }\end{array}$ & 44 & 63 & 70 \\
\hline $\begin{array}{c}\text { Biserica Ortodoxă } \\
\text { Greacă din Calendarul } \\
\text { Părinților - Sinodul } \\
\text { Celor Rezistenți }\end{array}$ & 9 & 12 & 12 \\
\hline $\begin{array}{c}\text { Arhiepiscopia } \\
\text { Bisericilor Ruse din } \\
\text { Occident } \\
\end{array}$ & 7 & 7 & 4 \\
\hline $\begin{array}{c}\text { Biserica Ortodoxă } \\
\text { Sârbă (Patriarhia } \\
\text { Serbiei) }\end{array}$ & 4 & 5 & 6 \\
\hline $\begin{array}{c}\text { Biserica Ortodoxă } \\
\text { Română a Calendarului } \\
\text { Vechi } \\
\end{array}$ & 3 & 4 & 4 \\
\hline $\begin{array}{c}\text { Biserica Ortodoxă } \\
\text { Autonomă a Europei } \\
\text { Occidentale și a }\end{array}$ & 3 & 14 & 14 \\
\hline
\end{tabular}




\begin{tabular}{|c|c|c|c|}
\hline $\begin{array}{c}\text { Americilor - Mitropolia } \\
\text { Milano și Ahileea }\end{array}$ & 2 & 2 & 2 \\
\hline $\begin{array}{c}\text { Biserica Ortodoxă } \\
\text { Bulgară (Patriarhia } \\
\text { Bulgariei) }\end{array}$ & 2 & 3 & 5 \\
\hline $\begin{array}{c}\text { Biserica Ortodoxă } \\
\text { Macedoneană }\end{array}$ & 1 & 1 & 1 \\
\hline $\begin{array}{c}\text { Biserica Ortodoxă Rusă } \\
\text { de Rit Vechi } \\
\text { (Mitropolia } \\
\text { Belokrinitsa) }\end{array}$ & 1 & 2 & 2 \\
\hline $\begin{array}{c}\text { Biserica Ortodoxă din } \\
\text { Italia }\end{array}$ & - & 5 & 5 \\
\hline $\begin{array}{c}\text { Biserica Ortodoxă } \\
\text { Autocefală Ucraineană } \\
\text { din diaspora }\end{array}$ & - & 443 & 516 \\
\hline $\begin{array}{c}\text { Biserica Ortodoxă } \\
\text { Georgiană }\end{array}$ & 326 & 10 & 10 \\
\hline Total & &
\end{tabular}

După cum reiese din Tabelul 4, cele trei jurisdicții principale din Italia sunt cele ale Bisericii Ortodoxe Române, Patriarhiei Ecumenice a Constantinopolului şi Bisericii Ortodoxe Ruse. În special, în 2020, Biserica Ortodoxă Română cuprinde $57 \%$ din parohiile ortodoxe din Peninsula Italiană, în timp ce Patriarhia Ecumenică 17\% și Biserica Rusă 13\%. Pe scurt, aceste trei jurisdicții cuprind $87 \%$ din parohiile ortodoxe din Italia. Din această perspectivă a cantității, articolul meu se va concentra pe stabilirea acestora din urmă în contextul italian. În acest sens, voi face referire şi la alte studii pentru o privire istorică de ansamblu asupra înființării acestor Biserici Ortodoxe în Italia, care par destul de diferite una de cealaltă (Giordan, Guglielmi 2018; Giordan 2015).

Conform datelor culese, numărul parohiilor ortodoxe prezente în fiecare regiune din Italia în 2020 pare să confirme principalele tendințe identificate la începutul anului 2016 (Giordan, Guglielmi 2018). Mai mult decât atât, datele despre 2020 par să se 
suprapună și cu estimările anterioare referitoare la distribuția ortodocşilor în Peninsula Italiană. În acest sens, regiunile cu cel mai mare număr de parohii sunt Lombardia și Lazio, principalele destinații ale religiilor imigrante din Italia, dar și Piemont, EmiliaRomagna și Veneto, care sunt zonele cu cele mai importante activități economice și de producție din țară. Locașurile de cult ortodoxe sunt prezente în toate marile orașe din toate regiunile italiene. $\mathrm{Cu}$ toate acestea, chiar dacă prezenţa lor este consistentă în nordul Italiei, este evident că numărul de parohii ortodoxe în zonele centrale (cu excepția Lazio) și în regiunile sudice (cu excepția Siciliei) este mai limitat.

Panorama creștin-ortodoxă din Italia pare a fi un scenariu fragmentat și eterogen, deoarece include jurisdicțiile a 7 Biserici Ortodoxe canonice și a 7 Biserici Ortodoxe necanonice. După cum s-a menționat în secțiunea anterioară, aceste 14 jurisdicții primesc credincioși nu numai din propriul lor grup național, ci și ,importă” pe teritoriul italian prin legături și procese transnaționale unele situații legate atât de conflictele ecleziastice, cât și de problema jurisdicțiilor multiple din patria lor de origine. De exemplu, ne referim din nou la distribuirea credincioșilor români între parohiile ortodoxe române și parohiile ortodoxe ruse/moldovenești; cea a credincioșilor ucraineni în parohiile ortodoxe ruse și parohiile Patriarhiei Ecumenice, precum și cea a credincioșilor în parohiile sârbe și cele macedonene. Mai mult decât atât, acest scenariu cuprinde și parohiile facțiunilor greco-române care aparțin tradiției ortodoxe a vechilor calendarişti, adică Bisericile Ortodoxe care nu au acceptat modificarea calendarului bisericesc tradiţional iulianconstantinian în 1924.

În acest context, menționăm, de asemenea, așezarea în orașul Torino a celei mai mari comunități de lipoveni români din Europa de Vest; probabil fiind asemănătoare ca mărime cu o altă comunitate de acest fel din Spania. Această religie a diasporei face parte din Biserica Ortodoxă Rusă de Rit Vechi, o biserică fidelă liturghiei originale care a început să se răspândească în întreaga lume la mijlocul anilor 1600, după reforma patriarhului Nikon, deoarece nu a acceptat unele dintre reformele sale în Biserica 
Ortodoxă Rusă. În cele din urmă, în 2016 s-a făcut senzaţie în lumea ortodoxă, iar atenția mass-mediei italiene a fost atrasă de încercarea unor clerici italieni, uneori foști catolici, de a constitui prima Biserică Ortodoxă Italiană. Astfel, ei au încercat să unească într-un statut autocefal comun mai multe unități religioase diferite din Italia ${ }^{5}$.

Aceasta panoramă creștin-ortodoxă sugerează că anumite forme de naţionalism nu mai sunt potrivite într-un context (gazdă) care forțează diferitele jurisdicții să interacționeze între ele la un nivel fără precedent în ceea ce privește situațiile patriei. În acest sens, exemplul Conferinței Episcopale Ortodoxe din Italia și Malta este o primă încercare de a stabili o coordonare panortodoxă între episcopii și Bisericile Ortodoxe canonice care au jurisdicție asupra teritoriului italian. Adunarea apare ca o instituție ortodoxă locală care încearcă să coordoneze diferite probleme și nevoi ale diasporei ortodoxe (canonice) într-o țară vest-europeană. În acest sens, având în vedere particularitatea diversității religioase din Italia şi hegemonia culturală a catolicismului în societate, conform ultimei estimări se poate observa un număr semnificativ de italieni convertiţi la Ortodoxie, adică 355.300 de persoane (CESNUR 2020). Prin urmare, ultima tendință ar putea remodela și mai mult relația socială mai convențională dintre identitatea națională și cea religioasă în Ortodoxie și ar putea influența următoarele relaţii între jurisdicțiile ortodoxe din diaspora.

În încheiere, putem argumenta că în cadrul acestei panorame, redistribuirea grupurilor naționale către jurisdicțiile diasporei ortodoxe îmbină tensiunile canonice ale patriei de baștină și a treburilor ortodoxe internaționale cu fațetele socio-culturale ale țării gazdă și aspectele tipice ale condiției diasporice. În secțiunea următoare, ne vom concentra pe relația mediului gazdă cu așezarea acestor religii ale diasporei; în această secțiune intenția noastră este de a sublinia modul în care țara gazdă poate redefini graniţele care afectează în mod normal suprapunerea identității naționale şi

${ }^{5}$ Un profil istoric al acestei biserici este disponibil pe site-ul Centrului de Studii privind Noile Religii (CESNUR), disponibil la: http://www.cesnur.com/lachiesa-ortodossa-italiana (accesat la data de 28 iunie 2018). 
religioase. În plus, configurația jurisdicțiilor diasporei ortodoxe într-o anumită țară pare să constituie un fel de „puzzle”, care nu poate fi ușor de identificat în alte contexte.

\section{Așezarea diasporelor ortodoxe în Peninsula Italiană}

În această secțiune, studiem așezarea diasporelor ortodoxe cu mediul gazdă, concentrându-ne pe unele căi de angajare a bisericilor acestea cu contextul italian. Din punct de vedere teoretic, indicațiile enumerate în tabelul următor sunt rezultatul elaborării principalelor studii empirice sociologice privind stabilirea diasporei ortodoxe (Hämmerli 2011; Hämmerli, Mayer 2014; Roudometof 2014; Krindach 2011, 2016; Giordan, Zrinšcak 2020). În acest sens, perspectiva largă adoptată pentru a analiza așezarea bisericilor ortodoxe se bazează pe noțiunea de „reflexivitate” dezvoltată de Lichterman (2005). Practic, se poate spune că un proces reflexiv este inițiat atunci când o religie a diasporei se angajează într-un dialog cu alte comunități sociale, culturale, religioase și politice din țara gazdă. Urmând această viziune principală, așa cum a fost prezentată în Tabelul 5, conturez înrădăcinarea unei biserici ortodoxe prin analizarea principalelor sale căi de implicare în mediul gazdă. Aceste din urmă căi sunt legate atât de dinamica și practicile din viața parohiilor, cât și de pozițiile generale ale eparhiei.

Tabelul 5. Colaborarea cu contextul socio-cultural al Bisericilor Ortodoxe din Italia

\begin{tabular}{c|c|c|c|c}
\hline $\begin{array}{c}\text { Diaspora } \\
\text { ortodoxă }\end{array}$ & Limbă & $\begin{array}{c}\text { Activitatea } \\
\text { pastorală }\end{array}$ & $\begin{array}{c}\text { Relațiile cu } \\
\text { Biserica } \\
\text { Catolică }\end{array}$ & $\begin{array}{c}\text { Relațiile } \\
\text { Biserică-Stat }\end{array}$ \\
\hline $\begin{array}{c}\text { Biserica } \\
\text { Ortodoxă } \\
\text { Română }\end{array}$ & $\begin{array}{c}\text { Română, română } \\
(\mathrm{M})^{6} \text {, Italiană }\end{array}$ & Înaltă & Bune & Niciun acord \\
\hline
\end{tabular}

${ }^{6}$ Români, cetățeni din Republica Moldova. 


\begin{tabular}{c|c|c|c|c}
\hline $\begin{array}{c}\text { Patriarhia } \\
\text { Ecumenică }\end{array}$ & $\begin{array}{c}\text { Greacă, română }(\mathrm{M}), \\
\text { Română, Italiană, } \\
\text { Slavonă }\end{array}$ & Scăzută & Bune & Acord \\
\hline $\begin{array}{c}\text { Biserica } \\
\text { Ortodoxă Rusă }\end{array}$ & $\begin{array}{c}\text { Slavonă, română } \\
(\mathrm{M}), \text { Italiană }\end{array}$ & Scăzută & Bune & Niciun acord \\
\hline
\end{tabular}

Utilizarea limbii societății gazdă este unul dintre principalii factori de integrare a diasporei. Acesta sprijină modificarea punctelor lingvistice și cognitive ale referințelor imigrantului și favorizează absorbția de noi practici și identități. În religiile diasporei, utilizarea acestei limbi în serviciile religioase ca limbă liturgică este un indiciu al profunzimii așezării religioase. Am cartografiat cele mai utilizate limbi din cele trei religii ale diasporei $\mathrm{cu}$ date colectate prin interviuri aprofundate cu liderii religioși ai acestor jurisdicții.

Limbile folosite în principal în parohiile diasporei ortodoxe românești sunt româna și italiana, iar limba română în parohiile formate din credincioșii care vin din Mitropolia Moldovei. Această Biserică din diaspora este în principal compusă din credincioși care au sosit din Patria Mamă și un mic grup de italieni care s-au convertit ca urmare a apariției căsătoriilor mixte. Documentarea și materialul eparhiei sunt substanțial bilingve, chiar dacă în Liturghie și în viaţa parohiei limba folosită este limba română. Spațiul pentru limba italiană este întotdeauna rezervat în sărbători, iar acest lucru va varia în ceea ce privește intensitatea și exprimarea de la parohie la parohie.

Pe de altă parte, în parohiile Patriarhiei Ecumenice limba folosită la liturghii este greaca veche și, în ordinea folosirii româna, italiana și slavona (și, sporadic, alte limbi ale țărilor răsăritene). Această pluralitate lingvistică pare să se datoreze setului eterogen de comunități naționale care formează corpul credincioșilor acestei religii a diasporei. Conform datelor pe care le-am cules de la Arhiepiscopia Veneției în anul 2016, comunitățile religioase ale acestei jurisdicții cuprind următoarele naționalități: greacă, cipriotă, italiană, română, ucraineană, 
georgiană, bulgară, sârbă și albaneză. După cum s-a subliniat în secțiunea anterioară, această religie a diasporei are capacitatea de a primi imigranți din diverse țări ortodoxe, în special din Moldova şi Ucraina. Mai mult decât atât, se pare că s-a dezvoltat o comunitate de italieni convertiți la Ortodoxie.

În cele din urmă, în Biserica Ortodoxă Rusă, limba liturgică este slavona, limba tradițională a Liturghiei. Conform datelor culese, este posibil ca această limbă să poată fi însoțită de o utilizare minoră a limbii române și, în unele cazuri, de italiană. Această religie a diasporei unește credincioșii din țările în care Bisericile Locale se află sub jurisdicția Patriarhiei Moscovei, în special din Moldova și Ucraina. Într-o măsură mai mică, de asemenea, adună credincioși și din alte țări ale fostului bloc comunist, cum ar fi Belarus, Estonia, Bulgaria și Serbia. Această compoziție a corpului credincioșilor în ansamblul său favorizează poziția centrală a limbii slave în slujbele religioase și a limbii ruse în viața parohiilor, precum și utilizarea limbii române în mai multe comunități.

În continuare, vom analiza în linii mari practicile religioase elaborate de Bisericile Ortodoxe din Italia. În ultimul deceniu, dieceza Bisericii Ortodoxe Române pare să fi elaborat un plan de activitate socială pe care 1-aș putea defini drept, ,inedit” în lumea ortodoxă. Așa cum a reieșit și în alte cercetări (Ihlamur-Öner 2009, 2014; Giordan, Guglielmi 2018; Guglielmi 2020; Ricucci 2017: 109-127; Harja, Melis 2010: 25-31), parohiile ortodoxe române au organizat asistență socială pentru comunitatea imigranților, dezvoltând căi importante de ajutor legate de nevoile comunităților locale, cum ar fi cele care implică marele fenomen social al îngrijitorilor români (Caselgrandi et alii 2013). De asemenea, parohiile au dezvoltat o activitate pastorală destinată tinerilor în principal prin tabere școlare studențești și activități sportive și muzicale în cadrul unor evenimente religioase, alături de alte obiceiuri noi, cum ar fi retragerile spirituale pentru clerul eparhiei. Presupun că Ortodoxia românească în Italia a inițiat un proces de reflecție cu privire la Biserica Romano-Catolică, din care a asimilat unele dintre practicile sale religioase. Așa cum am subliniat în 
introducere, această ipoteză provine dintr-o lungă cercetare empirică în care am intervievat în două rânduri episcopul și episcopul vicar al diasporei ortodoxe românești, care ne-au furnizat date și informații despre activitățile eparhiei utilizate în analiza sociologică, precum și clerici și credincioși români a Patriarhiei din Patria Mamă și a parohiilor din Italia.

Această atitudine faţă de reflexivitate și de dimensiune cantitativă a diasporei românești a dus la ,rezonanța” ei în sfera publică italiană. Participarea credincioșilor la sărbătorile religioase, în special cele organizate în spaţiul public ${ }^{7}$, a favorizat prezența frecventă a parohiilor românești în mass-media locală. Mai mult, în ultimii ani, episcopul Siluan (Șpan) al eparhiei române pare să fi dobândit o poziție aparte în mass-media catolică italiană ca lider religios al celei de-a doua mari comunităţi creștine din Italia.

Patriarhia Ecumenică a Constantinopolului se mândrește cu cea mai veche aşezare ortodoxă din Peninsula Italiană. Prezența comunităților ortodoxe grecești în Italia este legată de influența Imperiului Bizantin, care apare în special în regiunile din sudul Italiei în secolul al XV-lea (Ravegnani, 2004). Cu toate acestea, în ciuda acestei așezări pe termen lung, pe teritoriul italian, aceste parohii nu par să fi dezvoltat o formă specială de ,negociere” cu mediul gazdă. După cum reiese din datele colectate de la Episcopie, în 2016, cu privire la activitățile comunităților sale, parohiile se concentrează pe practicile mai tipice ale religiei creștine ortodoxe, cum ar fi lucrările caritabile (diakonia), activitatea de catehizare și cursuri de muzică bizantină și limbă greacă. Această eparhie organizează, de asemenea, Liturghii în spaţiul public, în particular unde sunt prezente principalele sale comunități, cum ar fi în orașele Veneția și Perugia.

În cele din urmă, Biserica Ortodoxă Rusă nu pare să fi elaborat procese relevante în contextul italian (așa cum pare că sugerează o cercetare privind comunitățile sale religioase din regiunea Emilia Romagna [Carnevale 2018]). Parohiile rusești par să-şi concentreze

${ }^{7}$ Un exemplu este sărbătoarea tradițională de Paște a comunității ortodoxe române din Torino într-o piață centrală a orașului (Cingolani 2011). 
atenția asupra câmpului liturgic și principalele practici „dincolo de altar" par să se concentreze asupra obiceiurilor ortodoxe în ceea ce privește lucrările caritabile și activitățile de catehism. Această biserică din diaspora are o relație pozitivă cu țesătura socială italiană, cultivată datorită prezenței sale pe termen lung în peninsulă (Talalay 1998). Pe de altă parte, nu pare să fi dezvoltat practici legate de mediul gazdă și de starea diasporei sale, nici vreo schimbare particulară favorizată de pluralitatea naționalităților credincioșilor săi. Pare să propună abordarea mai tipică a tradiției ortodoxe pentru abordarea problemelor societătii: combină diakonia cu pozițiile religioase orientate spre o perspectivă spirituală pentru a face față vieții sociale și provocărilor contemporane.

Cele trei religii din diaspora au relații bune cu Biserica Catolică. În general, parohiile lor aderă la instituțiile ecumenice locale, iar multe dintre lăcașurile lor de cult sunt situate în biserici ale eparhiilor catolice care sunt oferite câteva ore pe săptămână sau le sunt cedate pentru câțiva ani pe bază de împrumut pentru utilizare. $\mathrm{Cu}$ toate acestea, respectivele biserici din diaspora au stabilit o varietate de poziții faţă de religia dominantă din Italia, care sunt modelate atât de dinamica locală în mediul gazdă, cât şi de perspectiva ecumenică a bisericii de origine. În acest sens, pare oportun să subliniem gradul de influențare a proceselor transnaționale în influențarea acestor religii ale diasporei în Italia. Deși pare dificil de definit poziția diasporei ortodoxe în ceea ce privește relațiile catolico-ortodoxe, este posibil să fie înțelese unele „semne” care sugerează narațiunea sa principală față de catolicismul italian.

În acest sens, narațiunea principală a eparhiei românești din Italia pare legată de necesitatea redescoperirii „,rădăcinilor creștine” ale Europei. În această perspectivă, principala provocare a bisericilor europene se referă la obiectivul comun, cum ar fi apărarea identității creștine a continentului, precum și limitarea procesului de secularizare și de creștere a altor minorități religioase (Payne, Kent 2011) ${ }^{8}$. Patriarhia Ecumenică în Italia pare, în

8 De exemplu, această narațiune principală pare să fie identificabilă în trei interviuri ale episcopului Siluan pe canalele de televiziune italiene; disponibile la: https://www.youtube.com/watch?v=8909cw1I-hA; https://www.youtube. 
schimb, să-și găsească o poziție fructuoasă în exercitarea întâietății sale onorifice și în resentimentele oficiale ale întregii religii creștine ortodoxe din Italia. Prin rolul său principal de primus inter pares între Bisericile Ortodoxe, ea menține o poziție dominantă în cadrul relațiilor instituționale dintre aceste două ramuri ale creștinismului, la fel fiind și în dialogul ecumenic. În cele din urmă, Biserica Ortodoxă Rusă din Italia - ca și în cazul diasporei sale din Germania (Rimestad, Kadotschikow 2014) - pare să păstreze, întrun cadru cert pozitiv, o ,ambivalență” care alternează între o atitudine mai deschisă și alta mai închisă față de catolicismul italian, care se schimbă la nivel local ${ }^{9}$.

Toate cele trei Biserici din diaspora par să aibă o relație pozitivă cu instituțiile statului gazdă. Cu toate acestea, Patriarhia Ecumenică este singura jurisdicție ortodoxă care a ajuns la un acord cu statul italian, denumit „Intesa”. Acest acord, elaborat în 2007 și ratificat în iulie 2012, acordă practica sprijinului spiritual în cadrul serviciului național de sănătate și în structurile militare, precum şi recunoașterea unor festivități religioase. În plus, aceasta rezolvă problema efectului civil al căsătoriei religioase și oferă Patriarhiei Ecumenice anumite forme de ajutor economic, cum ar fi deducerea donațiilor în declarațiile fiscale de stat și participarea acesteia la așanumita convenție „Eight-per-one-thousand”, prin care o mică parte din impozitele generale colectate de stat pot fi donate instituţiilor religioase care au semnat acordul (Parlato 2012). În prezent, atât Episcopia Ortodoxă românească, cât și cea rusească sunt încă în curs de negociere a unui acord cu statul italian. Pentru aceste două biserici, nu sunt încă știri publice și dovezi care ar putea dezvălui etapele în curs ale proceselor de negociere pentru „Intesa”.

com/watch?v=FcAZfqpeUHM; https://www.youtube.com/watch?v=NNV8X9 nB734 (accesate la data de 20.10. 2021). Mai mult, la sediul Patriarhiei Române din București sala principală a fost redenumită „Europa Christiana” (Europa Creștină). Această alegere simbolică scoate în evidență adeziunea Ortodoxiei Românești la Uniunea Europeană și la spațiul pe care aceasta o rezervă viziunii sale ecumenice.

9 Această viziune a fost, de asemenea, confirmată de către Carnevale într-un interviu acordat în iunie 2018. Discutarea proiectul său de cercetare privind Bisericile Ortodoxe din regiunea Emilia-Romagna (Carnevale 2018). 


\section{Concluzii}

Cadrul adoptat în articolul de față a încercat să dezvolte o perspectivă sociologică mai degrabă decât una canonică pe tema diasporei ortodoxe din țările occidentale. Dacă prima se referă la actualele fațete socio-culturale și religioase ale acestor comunități religioase din străinătate, cea din urmă se referă în principal la problema juridică a jurisdicțiilor multiple din diaspora și la conflictele sale ecleziastice. În prima și a doua secțiune, am arătat cum diaspora ortodoxă dintr-o țară vest-europeană reprezintă un fel de „puzzle” care pare dificil de identificat într-un alt context. În acest sens, procesele imigranților și aspectele etnice și vernaculare ale comunităților ortodoxe păreau să re-contureze în cadrul jurisdicțiilor granițele care se suprapun, de obicei, identității naționale și religioase. În acest context, am acordat atenție migrației masive a ortodocșilor români în Italia, probabil datorită aspectelor etnice și vernaculare împărtășite cu italienii. În acest context larg, înrădăcinarea comunităților ortodoxe pare să favorizeze înființarea unei panorame creștine ortodoxe de frunte în Italia. În aceasta din urmă, redistribuirea grupurilor naționale în jurisdicțiile diasporei ortodoxe, combină tensiunile canonice ale patriei și ale chestiunilor ortodoxe internaționale cu fațetele socio-culturale ale țării gazdă și aspectele tipice ale situației diasporei.

În cea de-a treia secțiune, am explorat așezarea celor trei Biserici Ortodoxe principale din Peninsula Italiană. Diferitele căi de implicare a religiilor din diaspora au scos la iveală modul în care acestea dezvoltă diferite aspecte socio-culturale ale țării gazdă și elaborează o poziție religioasă diversă. Aceste biserici din diaspora, într-adevăr, par să întruchipeze procese de aşezare care nu sunt omogene între ele. Pe de-o parte, diferitele căi de implicare a diasporei ortodoxe evidențiază rolul jucat de factorii sociali, culturali, religioși și politici locali ai contextului italian. De exemplu, mă refer la impactul puternic al „,proximității culturale" specifice între italieni și români, care a influențat așezarea diasporei ortodoxe românști în Italia. Pe de altă parte, căile de angajament ale 
diasporei ortodoxe cu contextul italian dezvăluie impactul legăturilor lor transnaționale $\mathrm{cu}$ biserica de origine, așa cum a apărut mai clar în pozițiile lor ecumenice.

De fapt, înființarea diasporei ortodoxe în Italia ar putea avea efecte și asupra traiectoriilor viitoare ale Ortodoxiei răsăritene în teritoriile sale tradiționale. Acest scenariu a fost emis de mitropolitul Pergamului, Ioan Zizioulas, în lectio magistralis (2008) cu ocazia conferirii doctoratului onorific la Institutul Saint Serge din Paris, în 2008. El a declarat că respectivele comunităti ortodoxe diasporale din Europa Occidentală au dezvoltat noi practici față de lumea contemporană, ca urmare a relației lor cu țările gazdă și a statutului lor de minoritate religioasă. În viitorul apropiat, acestor diaspore ortodoxe li se va cere să „exporte” unele dintre aceste practici în patria lor, unde societățile se schimbă deja din cauza progresului secularizării și a proceselor de diferențiere religioasă. Acest punct de vedere prezentat de Zizioulas pare să ia în considerare schimbările recente ale creștinismului ortodox în scenariul global, care își asumă fațetele unei religii transnaţionale (Roudometof 2014; Giordan, Zrinšcak 2020). După cum sugerează studiul de caz privind creștinismul ortodox din Italia, această condiție recentă pare să sugereze evoluția (occidentală și europeană) a unei tradiții religioase care nu mai poate fi denumită în mod corespunzător doar orientală.

$\cos 80$

\section{Bibliografie}

1. ButTicCI, A., African Pentecostals in Catholic Europe: The Politics of Presence in the Twenty-First Century. Cambridge, MA, Harvard University Press, 2016.

2. CARneVAle, D. N., „I Cristianesimi ortodossi in Emilia Romagna: una mappatura", în I monoteismi in Emilia Romagna. Bologna, Edizioni Assemblea Legislativa Emilia Romagna, 2018.

3. Caselgrandi, N. / Rinaldi, A. / Montebugnoli A., (eds.), Se Due Milioni vi Sembran Pochi: Colf e Badanti nella Società Italiana di Oggi, Roma, Carocci, 2013. 
4. CESNUR (2020). Dimensioni del pluralismo religioso in Italia (2020), disponibil la: https://cesnur.com/dimensioni-delpluralismo-religioso-in-italia (accesat la data de 20.08.2021).

5. Cingolani, P., Romeni d'Italia: Migrazioni, vita quotidiana e legami transnazionali, Bologna, Il Mulino, 2009.

6. CingOlani, P., „Torino, Romania: Un Viaggio negli Spazi Urbani dell'Immigrazione Romena", în M. C. Belloni (ed.), Torino: Luoghi Urbani e Spazi Sociali, p. 53-65. Soveria Mannelli: Rubbettino, 2011.

7. GIORDAN, G., „Orthodox Christianity in Italy: Historical continuity and social discontinuity", în Religion, State and Society, 43, 3/2015, 262-275.

8. GioRdan, G., / Guglielmi, M., „Be fruitful and multiply... Fast! The spread of Orthodox Churches in Italy", în J. Stolz / C. Monnot (eds.), Congregations in Europe, p. 53-69. Cham: Springer, 2018.

9. Giordan, G. I ZRINŠCAK, S., Global Eastern Orthodoxy: Politics, Religion and Human Rights. Cham: Springer, 2020.

10. Guglielmi, M., „Orthodox Christianity in a Western Catholic Country: The Glocalization of Orthodox Diasporas in Italy", în G. Giordan / Zrinščak (eds.), Global Eastern Orthodoxy: Politics, Religion and Human Rights, Cham: Springer, 2020, p. 219-240.

11. GRIGORE, M., „Orthodox brothers’: Ecclesiastical jurisdiction, national identity, and conflict between the Romanian and Russian Orthodox Churches in Moldavia", în J. C. Wood (Ed.), Christianity and national identity in twentieth-century Europe: Conflict, community, and the social order, Göttingen: Vandenhoeck / Ruprecht, 2016, p. 91-110.

12. HÄMMERLI, M., „Orthodox diaspora? A sociological and theological problematization of a stock phrase", în International Journal for the Study of the Christian Church, 10, 2-3/2010, p. 97-115.

13. Hämmerli, M., Les Dimensions Plurielles de l'Intégration des Communautés Orthodoxes en Suisse, National research programme 58: Religion, the State and Society, final research report, 2011.

14. HÄMMERLI, M. / MAYER, J. F. (eds.), Orthodox Identities in Western Europe: Migration, Settlement and Innovation, Farnham: Ashgate, 2014. 
15. Harja, A. / Melis, G., Romeni: La Minoranza Decisiva per l'Italia di Domani, Soveria Mannelli: Rubettino, 2010.

16. IDOS, Dossier Statistico Immigrazione, Roma: Edizioni Idos, 2016.

17. IhlAMUR-ÖNER, S. G., The Romanian Orthodox Churches in Italy: The construction of Romanian-Italian transnational Orthodox space, $\mathrm{PhD}$ thesis, University of Trento, Trento, Italy, 2009.

18. IHLAMUR-ÖNER, S. G., „Romanian Orthodox Churches in Italy: The construction of the Romanian-Italian transnational Orthodox space", în M. Hämmerli / J. F. Mayer (eds.), Orthodox Identities in Western Europe: Migration, Settlement and Innovation, Farnham: Ashgate, 2014, p. 29-50.

19. ISMU, Immigrati e Religioni in Italia: Gli Ortodossi Sono Più Numerosi dei Musulmani. Report Fondazione ISMU, 2016, disponibil la: http://www.ismu.org/2016/07/in-italia-ortodossipiu-numerosi-dei-musulmani (accesat la data de 26.09.2021).

20. ISMU, Immigrati e religioni in Italia: $i$ cristiani sono più del doppio dei musulmani, 2020, disponibil la: https://www.ismu.org/immigrati-e-religioni-in-italia-i-cristianisono-piu-del-doppio-dei-musulmani-comunicato-stampa-22-62021 (accesat la data de 20.07.2021).

21. KRINDATCH, A., Atlas of American Orthodox Churches, Brookline: Holy Cross Orthodox Press, 2011.

22. KRINDATCH, A., Atlas of American Orthodox Christians monasteries, Brookline: Holy Cross Orthodox Press, 2016.

23. LiChTERMAN, P., Elusive togetherness: Church groups trying to bridge America's divisions, Princeton: Princeton University Press, 2005.

24. PACE, E., Vecchi e Nuovi Dei: La Geografia Religiosa dell'Italia che Cambia, Cinisello Balsamo: Paoline Editoriale Libri, 2011.

25. PACE, E. (ed.), Le Religioni nell'Italia che Cambia: Mappe e Bussole, Roma: Carocci, 2013.

26. PARLATO, V., „La Legge n. 126 del 2012 Relativa ai Rapporti tra Italia e Sacra Arcidiocesi Ortodossa d'Italia e Malta", în Stato, Chiese e Pluralismo Confessionale, 36/2012.

27. PAYNE, D. P., / KENT, J. M., „An alliance of the Sacred: Prospects for a Catholic-Orthodox partnership against secularism in Europe", în Journal of Ecumenical Studies, 46, 1/2011, p. 41-66. 
28. PoP, I. A., Romanians and Romania: A Brief History, New York: Columbia University Press, 1999.

29. RAVEGnANI, G., I Bizantini in Italia, Bologna: Il Mulino, 2004.

30. RicuCCI, R., Diversi dall'Islam: Figli dell'Immigrazione e Altre Fedi, Bologna: Il Mulino, 2017.

31. RIMESTAD, S. / KADOTSCHIKOW, E., „The ambivalent Ecumenical relations among Russian Orthodox faithful in Germany", în M. Hämmerli / J. F. Mayer (eds.), Orthodox Identities in Western Europe: Migration, Settlement and Innovation, Farnham: Ashgate, 2014, p. 74-82.

32. RIMESTAD, S., Orthodox Christian Identity in Western Europe: Contesting Religious Authority, Abingdon: Routledge, 2020.

33. Roudometof, V., Globalization and Orthodox Christianity: The transformations of a reli- gious tradition, London/New York: Routledge, 2014.

34. RoudometoF, V., „Special section: Orthodox Christianity in Western Europe", Religion, State, and Society, 43, 3/2015, p. 1-2.

35. Talalay, M., „Ortodossia Russa in Italia”, Religioni e società, 30, 1998, p. 90-98.

36. ZIZIOUlas, J., Il Contributo della Teologia Ortodossa Occidentale. Paris: Institut de Théologie Orthodoxe Saint-Serge, 2008, disponibil la: http://www.esarcato.it/ archivio_testi/ theologica/teologia_ortodossa_occidentale.pdf. (accesat la data de 26.07.2021). 